\title{
Job satisfaction and absenteeism of professionals in the Academia da Cidade Program in Brazil
}

\author{
Satisfação no trabalho e absenteísmo dos profissionais no Programa Academia \\ da Cidade no Brasil
}

\section{AUTHOR'S \\ Amanda Emmanuelly de Melo Tavares \\ Albuquerque $^{1}$ (D) \\ Bruno César Rodrigues da Silva ${ }^{1}$ \\ Emmanuelly Correia de Lemos² (iD \\ Vanessa Luiza Gomes de Moura ${ }^{1}$ \\ Charles Barbosa Gomes da Silva ${ }^{1}$ (D) \\ Alany de Mesquita Marins ${ }^{1}$ \\ 1 Programa Academia da Cidade. Secretaria \\ Municipal de Saúde do Recife. Escola Superior \\ de Educação Física, Universidade de Pernambuco, \\ Pernambuco, Brasil. \\ 2 Escola de Governo em Saúde Pública de \\ Pernambuco. Secretaria Estadual de Saúde de \\ Pernambuco. Escola Superior de Educação Física \\ Universidade de Pernambuco, Pernambuco, Brasil.}

\section{CORRESPONDING}

Amanda Emmanuelly de Melo

Tavares Albuquerque

amandaemt@hotmail.com

Rua João Fragoso de Medeiros, 1471 B1. A06 apto 04 - Candeias, Jaboatão dos Guararapes, Pernambuco, Brasil.

CEP: 54430-250.

DOI

$10.12820 /$ rbafs. $25 \mathrm{e} 0164$

\section{(cc) BY}

This work is licensed under a Creative Commons Attribution 4.0 International License.

\begin{abstract}
The aim of the study was to describe the level of satisfaction and absenteeism in the work of professionals in the Academia da Cidade Program (ACP). For this, a cross-sectional, descriptive study with a mixed approach was carried out. For data collection, a self-administered questionnaire was used for 104 professionals of the Program in Recife, Pernambuco. For the analysis of the quantitative data, the software SPSS v.10.0 was used, the results were shown in absolute and relative frequencies. Content analysis was carried out for the open questions about job satisfaction. The professionals stated that they were satisfied with the work, both from the point of view of the management of the Program (66.3\%), and in a global manner (63.5\%). The link with the users, the performance in health promotion and the teamwork were the aspects that most positively influenced job satisfaction and, conversely, the physical and material structure, the municipal macro management and the salary were those that contributed to the dissatisfaction of the professionals. Absenteeism due to sick leave (66.3\%) was the main reason for the withdrawal of professionals from work, and the support of the worker's health specialized team from the municipal health department was not perceived. It can be said that the professionals were satisfied with the work in the ACP, but the working conditions, the remuneration and the valorization from the management are aspects that must be improved. It is also necessary to take care of the provider, since absenteeism due to medical causes, withdrew almost half of the professionals in the period studied.
\end{abstract}

Keywords: Motor activity; Health promotion; Absenteeism; Job satisfaction; Worker's health.

\section{RESUMO}

O objetivo do estudo foi descrever o nivel de satisfação e o absenteísmo no trabalho dos profissionais do Programa Academia da Cidade (PAC). Para isso, foi realizado um estudo transversal, descritivo, de abordagem mista. Para coleta de dados foi utilizado um questionário autoaplicado para 104 profissionais do Programa em Recife, Pernambuco. Para análise dos dados quantitativos foi utilizado o software SPSS v.10.0, sendo os resultados em frequências relativas e absolutas. Para as questôes abertas sobre satisfação no trabalho foi realizada análise de conteúdo. Os profissionais afirmaram estarem satisfeitos no trabalho tanto do ponto de vista da gestão do Programa (66,3\%), quanto de uma maneira global (63,5\%). O vínculo com os usuários, a atuação na promoção da saúde e a equipe de trabalho foram os aspectos que mais influenciaram positivamente a satisfação no trabalho e de forma contrária, a estrutura física e material, a gestão macro municipal e o salário foram os que contribuíram para a insatisfação dos profissionais. O absenteísmo por licença médica $(57,7 \%)$ foi o motivo principal do afastamento dos profissionais do trabalho e não tiveram o apoio da equipe especializada em saúde do trabalhador da secretaria de saúde municipal. Pode-se afirmar que os profissionais estavam satisfeitos com o trabalho no $P A C$, porém as condiçôes de trabalho, a remuneração e a valorização da gestão são aspectos que devem ser melhorados. Faz-se necessário também o cuidado ao cuidador, já que o absenteísmo por causas médicas, afastaram quase metade dos profissionais no periodo estudado.

Palavras-chave: Atividade motora; Promoção da saúde; Absenteísmo; Satisfação no trabalho; Saúde do trabalhador.

\section{Introduction}

The Academia da Cidade Program (ACP), was implemented in Recife, Pernambuco (PE) by means of a municipal decree from the health department and later became a municipal strategy of the National Health Promotion Policy in Primary Care ${ }^{1}$. The Program's general objective is to contribute to the promotion of collective health through the development of physical activity, leisure and guidance for the adoption of healthy eating habits, enhancing the use of public spaces, promoting social protagonism, aiming at improving the quality of life of the population of Recife ${ }^{1}$. 
The interventions of the ACP take place in requalified public places called hubs; in health facilities, such as psychosocial support center (PSCs), therapeutic shelter, family health unit, health centers / basic health unit; social facilities; and, yet, in other public spaces identified as possible for the performance of the Program ${ }^{1}$.

The activities of the ACP are carried out from monday to friday in the morning, afternoon and evening shifts with the workload divided between the pole and other health and social equipment adjusted according to the locations and action plans built by the Program team and agreed with the community ${ }^{1}$.

All ACP professionals are Physical Education professionals hired through public examinations. According to Municipal Law² no 17.400 / 2007 which addresses the creation of the position. These professionals make up the primary health care teams of the Department of Health, and are responsible for organizing, planning, and providing technical support for the elaboration, application and development of body practices and physical activities in the municipal health network. Moreover, they must develop actions with a view to promoting health and combating violence; also they must conduct an active search for users with the apparatus of the Department of Health, the community and instances of social control and encourage the inclusion of people with disabilities, the elderly and people with chronic diseases, among others, in projects of body practices and physical activities ${ }^{2}$.

It is worth mentioning that the activities described above are developed by professionals within the scope of the Unified Health System - Sistema Único de Saúde (SUS). The ACP is an integral part of this system, so many issues related to work and health workers have gained importance since the creation of the SUS in view of the changes and challenges placed on work, and on the organization of work in health. The conformation of live work in action is emphasized, therefore the meeting between the user and the workers is of great importance for the dynamics of the performance of health workers ${ }^{3}$.

The National Health Policy for Workers ${ }^{4}$ suggests that managers and health professionals should develop strategies to identify situations that result in hazards or risks to health, adopting or controlling feasible measures when necessary. This presupposes the understanding that workplaces are spaces of public interest, and it is up to the SUS to assume its sanitary and constitutional responsibility to protect the health of workers in their workplaces.

Therefore, understanding that among the various aspects related to work, there is job satisfaction, which is the sum of the different feelings that the worker manifests in relation to his work activity, permeated by intrinsic and extrinsic aspects. Since job satisfaction is one of the dimensions that generate health, and in a contrary way dissatisfaction can cause physical, mental and social damage ${ }^{5}$.

In addition to job satisfaction, another aspect related to work is absenteeism at work, which means the lack of assiduity of the worker in his work activity. It is known that there may be several reasons for leaving work, i.e.: health problems, accidents at work, health problems in the family members, pregnancy and childbirth, marriage (gala leave), study leave, unpaid leave, grieving leave (sick leave). Furthermore, fouls that are not legally justified may occur ${ }^{6}$.

Given the characteristics of the work of professionals in the ACP, the following aspects were observed in this study: the orthostatic position, repetitive movements, long hours taught in the same work shift, impacting the provider on this outcome ${ }^{7}$. Moreover, such professionals also need to be attentive and aligned with their professional performance concerning the field of knowledge, the field of collective health, the Program's interventions principles and guidelines of The SUS and of Health Promotion should be also included ${ }^{8}$.

These were the two aspects defined to be investigated in this study, given the characteristics of work in the $\mathrm{ACP}$ that at the same time have characteristics of their core of activity that lead professionals to maintain in the orthostatic position for long hours, repetitive movements, teach several classes in the same work shift, so they are functions subject to different overloads ${ }^{7}$. As they also need to be attentive and aligned with a professional practice related to the field of knowledge, to the field of collective health, and should promote interventions based on the principles and guidelines of the SUS and Health Promotion ${ }^{8}$.

Thus, it is expected with this study, to contribute with the theoretical and practical reflections on the health of the worker, in this case, of the physical education professional of the ACP, and when it fits for similar programs, from the thinking and acting of the worker's health in the SUS. Thus, the present study aims to describe the level of satisfaction and absenteeism in the work of ACP professionals.

\section{Method}

A cross-sectional descriptive study with a quantitative 
approach was conducted, originated from a research project entitled "Inclusion of the Academia da Cidade Program in Primary Health Care in the City of Recife: Perception of Academia da Cidade Program and Primary Health Care Professionals." which was prepared by ACP's professionals to conclude the post-graduation lato sensu Physical Activity and Public Health, promoted by the Municipal Secretariat of Recife in partnership with the University of Pernambuco in response to the demand of the Program professionals focusing on permanent education spaces. The study site was the 41 poles of the Academia da Cidade Program in the city of Recife, distributed in eight health districts. The study population consisted of 118 Physical Education professionals from the ACP. It is worth noting that the $\mathrm{ACP}$ has a total of 182 professionals, of these 64 were excluded from the study because they had at least one exclusion criterion (professionals who at the time of the research were away by medical certificate, vacation, maternity leave, award or study, those who worked at the Ermírio de Moraes Medical Center and the UPE Experimental Pole were excluded, in addition to the professionals who were part of the program coordination and the participants of the research team of this study) the others entered the inclusion criterion that was to be working in the ACP. Of the 118 professionals eligible to participate in the research, two refused and 12 were considered losses, totaling the final sample with 104 ACP professionals.

The data collection instrument was a self-administered questionnaire to the professionals at the ACP centers. This was prepared with objective questions, based on the reality of the Program. To reduce the limitations of the questionnaire, a pilot test was applied before its definitive use. The questionnaire was organized into ten sessions, namely: (1) sociodemographic and professional, (2) role in the ACP, (3) extra hub activities, (4) physical structure, equipment, materials, cleaning and safety, (5) district meeting, (6) training meeting, (7) level of satisfaction, (8) absenteeism, (9) social control and (10) articulation with primary health care.

The variables analyzed in this study were sociodemographic in order to characterize the population, job satisfaction and absenteeism. For this, the interviewees answered a questionnaire with their sociodemographic data, and six other questions related to the level of satisfaction (four questions on the professional's perceptions about the program management, the program itself, starting date, and, activity in the program, and of two open questions, that listed the main aspects of his/her satisfaction and dissatisfaction) and five questions about absenteeism (if the professional left for any leave permitted by law, for sick leave, how many days were necessary in case of sick leave and if he/she was referred for treatment within the health network itself, by the municipal worker health sector or by the direct management of the program).

Data collection involved graduate students from the University of Pernambuco (students participating in this study), previously trained (prior training was carried out for the entire team) to apply the questionnaire. Data collection took place through pre-scheduled visits, primarily at the district meetings, then at the permanent education meetings and finally at the poles. It was held from July to August 2015.

The data compilation procedure was performed using the EpiData Entry program (version 3.1). For the analysis of quantitative data, SPSS version 10.0 software was used, with results in relative and absolute frequencies. For the open questions, content analysis was performed according to Bardin's proposal ${ }^{9}$ : data ordering, rereading and data coding. Then, the answers were separated by categories, and finally, an analysis dialoguing with the literature was performed.

The research project to which this study is linked -was approved by the Ethics Committee in Research with Human Beings at the University of Pernambuco through opinion No. 1,138,920. The subjects' participation was voluntary and by signing the Informed Consent Form.

\section{Results}

The sample of the present study was composed of 104 ACP Physical Education professionals. 61.5\% were women, aged between 30-39 years old, $76.9 \%$ were married and $65.4 \%$ in a stable relationship. The majority, $67.3 \%$, had a specialization course with a higher level of education, 95.2\% had a full B.A degree in Physical Education, and $85.6 \%$ had no discipline on public health or collective health, as well as $71.2 \%$ did not have an internship at the SUS. The highest percentage, $35.6 \%$, stated that they had a weekly workload of 41 to 60 hours (adding up to those worked at ACP and other employment relationships), 76.9\% received between 3 and 6 minimum salaries, $37.5 \%$ have been in public health for three years and $73.1 \%$ of professionals have not received specific training or training to work in the Program (Table 1). 
Table 1 - Description of socio-demographic and training profile of ACP professionals, Recife, Pernambuco, Brasil, 2015

\begin{tabular}{|c|c|c|}
\hline Variable & $\mathrm{n}$ & $\%$ \\
\hline \multicolumn{3}{|l|}{ Sex } \\
\hline Female & 64 & 61.5 \\
\hline Male & 40 & 38.5 \\
\hline \multicolumn{3}{|l|}{ Age } \\
\hline 20 to 29 & 4 & 3.8 \\
\hline 30 to 39 & 80 & 76.9 \\
\hline 40 to 49 & 18 & 17.3 \\
\hline 50 a 59 anos & 2 & 1.9 \\
\hline \multicolumn{3}{|l|}{ Education } \\
\hline Under Graduation & 27 & 26 \\
\hline Specialization & 70 & 67.3 \\
\hline Internhsip & 4 & 1.0 \\
\hline Masters & 6 & 5.8 \\
\hline \multicolumn{3}{|l|}{ Degree obtained } \\
\hline Full Teaching Degree & 99 & 95.2 \\
\hline Teaching Degree & 2 & 1.9 \\
\hline B.A & 1 & 1.9 \\
\hline Teaching Degree and B.A & 1 & 1.0 \\
\hline Not answered & 1 & 1.0 \\
\hline \multicolumn{3}{|c|}{ Public Health Subject at the Undergraduation } \\
\hline Yes & 89 & 14.4 \\
\hline No & 15 & 85.6 \\
\hline \multicolumn{3}{|l|}{ Internship in Public Health } \\
\hline Yes & 28 & 26.9 \\
\hline No & 74 & 72.5 \\
\hline \multicolumn{3}{|l|}{ Training to work in PAC } \\
\hline Yes & 28 & 26.9 \\
\hline No & 76 & 73.1 \\
\hline \multicolumn{3}{|l|}{ Weekly workload } \\
\hline$<20$ hours & 17 & 16.3 \\
\hline 21 a 40 hours & 27 & 26.0 \\
\hline 41 a 60 hours & 37 & 35.6 \\
\hline$>61$ hours & 14 & 13.5 \\
\hline Not answered & 9 & 8.7 \\
\hline
\end{tabular}

Regarding satisfaction with the ACP, it was observed that most professionals considered the performance of the ACP management (66.3\%) and the Program in general (56.7\%) to be good. At the beginning of ACP activities, most professionals were satisfied (70.2\%) and are still satisfied (63.5\%) with the Program. No one reported being dissatisfied $(0,0 \%)$ at the start of the activities, however, then, $4.8 \%$ of the interviewees were dissatisfied (Table 2).

When assessing which are the main aspects that make professionals satisfied with the work at ACP, the answers were divided into 3 categories: 1st. relationship and benefits to users, for example: "the relationship I participation of users", "results in people and being able to contribute with them", "social interaction", "improving
Table 2 - Description of the assessment of the level of satisfaction of ACP workers, Recife, Pernambuco, Brasil, 2015

\begin{tabular}{lcc}
\hline \multicolumn{1}{c}{ Variable } & $\mathrm{n}$ & $\%$ \\
\hline Program management performance & 6 & 5.8 \\
Bad & 22 & 21.2 \\
Regular & 69 & 66.3 \\
Good & 7 & 6.7 \\
Very Good & & \\
The Program as a whole & 2 & 1.9 \\
Bad & 37 & 35.6 \\
Regular & 59 & 56.7 \\
Good & 5 & 4.8 \\
Very Good & & \\
How did you feel when you started activities in the & & \\
Program & 9 & 8.7 \\
Somewhat satisfied & 73 & 70.2 \\
Satisfied & 22 & 21.2 \\
Very Satisfied & & \\
How do you feel currently working on the Program & 5 & 4.8 \\
dissatisfied & 28 & 26.9 \\
Somewhat satisfied & 66 & 63.5 \\
Satisfied & 4.8 \\
Very Satisfied & 1 & 1.0 \\
Not answered & & \\
\hline
\end{tabular}

the user's quality of life" and "users"; 2 nd. Characteristics of the work, for example: "being able to act in the health promotion / public health policy", "the place where the activity is developed" and "identification through work"; 3rd. Teamwork, for example: the "bub team", the "relationship with the hub colleagues".

Among the factors that made professionals dissatisfied were: 1st. physical and material structure: "lack of physical structure and inadequate materials or in poor condition", the "precarious material", "lack of structure (equipment) to carry out the activities", "the physical structure of the bub" and "leaning". 2nd. Management commitment to the ACP: "lack of management support and investment (health district/ health secretariat and central level)", "lack of management commitment to the ACP and its professionals" and "lack of professionals (human Resources)"; 3rd. Professional remuneration: "low salary", "low remuneration", "lagged salary" and "lack of equalization with other health professionals".

As for the absenteeism of professionals, based on the statute of the municipal employees of 2014, maternity leave represented $4.8 \%$, paternity leave $3.8 \%, 1.9 \%$ of the professionals requested leave due to mourning leave, $2.9 \%$ for gala leave and 3.8\% were absent for accompanying leave. On the other hand, the request for sick leave represented the largest part of absences from work (42.3\%) at the ACP in that year (Table 3). 
Table 3 - Description of the licenses allowed by law that were requested by ACP professionals in 2014. Recife, Pernambuco, Brasil, 2015

\begin{tabular}{|c|c|c|}
\hline Variables & $\mathrm{n}$ & $\%$ \\
\hline \multicolumn{3}{|c|}{ Maternity leave } \\
\hline No & 99 & 95.2 \\
\hline Yes & 5 & 4.8 \\
\hline \multicolumn{3}{|c|}{ Paternity leave } \\
\hline No & 100 & 96.2 \\
\hline Yes & 4 & 3.8 \\
\hline \multicolumn{3}{|c|}{ Unpaid leave } \\
\hline No & 104 & 100.0 \\
\hline \multicolumn{3}{|c|}{ Mourning Leave } \\
\hline No & 102 & 98.1 \\
\hline Yes & 2 & 1.9 \\
\hline \multicolumn{3}{|c|}{ Study Leave } \\
\hline No & 104 & 100.0 \\
\hline \multicolumn{3}{|c|}{ Gala Leave } \\
\hline No & 101 & 97.1 \\
\hline Yes & 3 & 2.9 \\
\hline \multicolumn{3}{|c|}{ Accompanying license } \\
\hline No & 100 & 96.2 \\
\hline Yes & 4 & 3.8 \\
\hline \multicolumn{3}{|l|}{ Sick leave } \\
\hline No & 60 & 57.7 \\
\hline Yes & 44 & 42.3 \\
\hline
\end{tabular}

Of sick leave, the highest prevalence was due to musculoskeletal problems (76\%) followed by several surgeries (7.0\%), as shown in Figure 1. Of these, 17.3\% were absent from 3 to 10 days, $6.7 \%$ from 11 to 20 days, $3.8 \%$ from 21 to 30 days, leaves of over 30 days represented $11.5 \%$ of the sample.

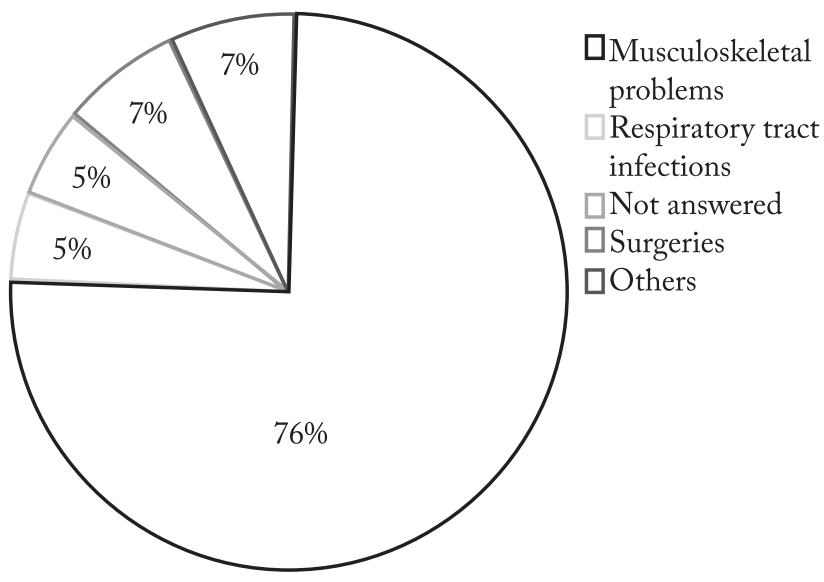

Figure 1 - Diseases that led ACP professionals to request sick leave from work in 2014. Recife, Pernambuco, Brasil, 2015 ( $n=104$ )
As for the referral of ACP professionals to the workers' health sector in the municipality, $37.5 \%$ reported negatively. Finally, it was asked whether during the sick leave the ACP coordination had provided a replacement, $21.2 \%$ reported negatively (Table 4 ).

Table 4-Distribution of professionals referred to the occupational health sector in 2014 and professionals who were replaced during their leave. Recife, Pernambuco, Brasil, 2015

\begin{tabular}{lcc}
\hline Variables & $\mathrm{n}$ & $\%$ \\
\hline Professionals referred to the CEREST & 39 & 37.5 \\
No & 1 & 1.0 \\
Yes & 60 & 57.7 \\
Not applicable & 4 & 3.8 \\
Not answered & & \\
Service to which the employee was referred & 103 & 99.0 \\
Not referred & 1 & 1.0 \\
Occupational doctor & & \\
Replacement of absences by leave & 22 & 21.2 \\
No & 21 & 20.2 \\
Yes & 60 & 57.7 \\
Not applicable & 1 & 1.0 \\
Not answered &
\end{tabular}

\section{Discussion}

The findings revealed that job satisfaction was reported by ACP professionals both from the point of view of the Program's management and globally. The link with the users, the performance in health promotion and the teamwork were the aspects that most influenced job satisfaction, whereas the physical and material structure, the municipal macro management and the salary were the ones that contributed to professional dissatisfaction. Absenteeism due to sick leave was the main reason for the absence of these professionals from work, as well as not having the support of the specialized team in the municipal workers' health department.

Regarding the profiles of ACP professionals, they were similar to the findings in other investigations in which the majority was female, aged between 30 and 39 , and only a small proportion of workers from programs similar to ACP had experiences related to the initial training in the SUS ${ }^{10-12}$.

In general, most professionals were satisfied with the ACP. Studies ${ }^{13-16}$ pointed out that time and experience increase the degree of worker satisfaction due to interpersonal relationships from both students and the 
teamwork, and the professional identification.

The main factors for satisfaction related to the users, such as, social interaction, bond, identification with work, the perception of contributing to improving people's quality of life and acting in public health are in line with the results found in other studies ${ }^{17-20}$, in which the identification with work, the principles of the Family Health Strategy, relationships with users and labor features are among the influencers of satisfaction in teamwork. Regarding job satisfaction, other studies ${ }^{17,19,21-23}$ have also indicated in their results as determining factors for dissatisfaction, the working conditions, such as the lack of adequate physical structure and the matter of supply and equipment acquisition and / or maintenance. What reverberates in another aspect found in this study that is related to the negative evaluation by professionals regarding the macro management of the municipal health department, which is stated as the lack of commitment of this management with the ACP, contributing with their dissatisfaction with their work in the Program, since it is an institutional responsibility ${ }^{19}$. Another point was the remuneration negatively interferes with the satisfaction of the professional, which may cause withdrawal and disinvestment ${ }^{19,21}$.

As for absenteeism, the results indicated that medical causes were the most prevalent one for the leaves at the ACP professionals, and the most common ones were musculoskeletal problems, corroborating with the same finding of Leão et al. ${ }^{24}$ in his study with public servants in the municipality of Goiânia, Goiás. It was mentioned that this absenteeism affects a large proportion of laborers of working age, with a direct impact on their quality of life and work capacity. The limitation of specific studies evaluating what impacts the withdrawal of Physical Education professionals in programs similar to the ACP makes it difficult a further comparison among studies, but the same discussion is brought up, that the health of this worker needs to find prominence in the public health debates.

It was found that the municipal worker's health service needs to act closer to the ACP personnel, meeting the recommendations of the National Worker Health Policy ${ }^{4}$.

Therefore, the well-being of the worker must have the same importance of care for the patient / user of the health services, as there is no care for the provider absent from work, and as it is a public policy, it must be implemented in its entirety. Because, in this way, the population will benefit from the professional working in the service, the management will offer a quality service and the worker will have more quality and satisfaction in his/her working life.

Limitations of this study are considered the size of the questionnaire and the memory bias regarding the questions about the leaves, as the subjects were liable to forget past facts. In order to minimize them, collections were always carried out in an agreed manner with the professionals according to their availability and without defining a specific time to answer the questionnaire.

Finally, it can be said that the professionals were satisfied with the work at the ACP, with emphasis on the bond with the users, the teamwork, and the work for health promotion with aspects that contributed to the referred result. On the other hand, dissatisfaction was related to working and managerial conditions. Absenteeism due to medical causes, musculoskeletal diseases, withdrew almost half of the professionals in the year studied.

The Municipal management of the health department should consider the findings herein, but also because job satisfaction and absenteeism interfere with the service provided to the population. It is also necessary that the Program checks continuously the aspects investigated here, for the development of systematic actions that will have an impact on the health of these workers. More researches with complex approaches are recommended, so that it is possible to deepen other questions that were not raised in this paper.

\section{Conflict of interest}

The authors declare no conflict of interest.

\section{Authors' contributions}

Albuquerque AEMT, participated in the initial study design, data collection and analysis, writing and critical review of the text. Silva $\mathrm{BCR}$, participated in the initial study design, data collection and analysis, writing and critical review of the text. Lemos EC, contributed to the initial study design, data analysis, writing and critical review of the text. Moura VLG, was responsible for the literature search, data collection and critical text review. Silva CBG, participated in the literature search, data collection and critical text review. Marins AL, contributed to the literature search, data collection and critical text review. All authors approved the final version.

\section{Acknowledgment}

The authors would like to thank the professionals of ACP, the City of Recife, ACP and the University of Pernambuco. 


\section{References}

1. Lemos EC, Gouveia GC, Luna CF. Programa Academia da Cidade: a experiência do Recife. In: Gurgel IGD, Medeiros KR, Aragão AV, Santana RM (eds). Gestão em Saúde Pública: Contribuições para a Política. Recife: Editora UFPE; 2014.p. 139-53.

2. Prefeitura da cidade do Recife. Lei 17400 de 2007. [citado em 2020 abr 21]. Disponível em: https://leismunicipais. com.br/a/pe/r/recife/lei-ordinaria/2007/1740/17400/leiordinaria-n-17400-2007-cria-cargos-efetivos-no-ambitoda-administracao-direta-do-municipio?q=17400.

3. Fischborn AF, Cadoná MA. Trabalho e autonomia dos trabalhadores em saúde: considerações sobre pressupostos teórico e metodológicos de análise do trabalho em saúde. Saúde Soc. 2018;27(1):227-37.

4. Brasil. Política Nacional de Saúde do Trabalhador e da Trabalhadora. Portaria GM/MS n ${ }^{\circ} 1.823,23$ de agosto de 2012. Diário Oficial da República Federativa do Brasil. Brasília, 165, p.46-51, 24 ago.2012. Seção 1. [citado em 2020 abr 10]. Disponível em: http://fasubra.org.br/wp-content/ uploads/2014/11/Portaria_1823_12_institui_politica.pdf.

5. Oliveira IB, Ribeiro AB, Afonso MR. Satisfação com a profissão: um estudo com professores de Educação Física. Pensar a Prát. 2018;21(1):82-95.

6. Gerring Junior G, Corrêa Filho HR, Vieira Neto JD, Ferreira NA, Vieira SVR. Absenteísmo-doença entre profissionais de enfermagem da rede básica do SUS Campinas. Rev Bras Epidemiol. [online].2007;10(3):401-9.

7. Mohr PA, Guimarães AV, Barbosa AR. Sintomas de distúrbios osteomusculares em profissionais de educação física, atuantes em academias de Florianópolis-SC. Rev Bras Ciênc. Esporte [online]. 2011;33(4):1041-53.

8. Brasil. Ministério da Saúde. Secretaria de Vigilância em Saúde. Secretaria de Atenção à Saúde. Política Nacional de Promoção da Saúde: PNPS: Anexo I da Portaria de Consolidação no 2, de 28 de setembro de 2017, que consolida as normas sobre as políticas nacionais de saúde do SUS/ Ministério da Saúde, Secretaria de Vigilância em Saúde, Secretaria de Atenção à Saúde. Brasília: Ministério da Saúde, 2018. [citado em 2020 abr 22]. Disponível em: https://bvsms.saude.gov.br/bvs/ publicacoes/politica_nacional_promocao_saude.pdf.

9. Bardin L. Análise de Conteúdo. 3a ed.Lisboa: Edições 70, 2011.

10. Rodrigues JD, Ferreira DK, Farias Junior JC, Caminha IO, Florindo AA, Loch MR. Perfil e atuação do Profissional de Educação Física nos Núcleos de Apoio à Saúde da Família na região metropolitana de João Pessoa, PB. Rev Bras Ativ Fís Saúde. 2015; 20(4):352-65.

11. Oliveira DCR, Lemos EC, Silva CRM, Tassitano RM. Professional competency of the professionals of physical activity programs of the Pernambuco primary health care. Rev Bras Ativ Fís Saúde. 2018;23:e0022.
12. Neves RLR, Assumpção LOT. Formação e intervenção profissional em saúde pública: percepções de profissionais de Educação Física. Movimento. 2017;23(1):201-12.

13. Capelo R, Pocinho M. Autoeficácia docente: predição da satisfação dos professores. Educar Rev. 2014;54:175-84.

14. Farias GO, Both J, Folle A, Pinto MG, Nascimento JV. Satisfação no trabalho de professores de educação física do magistério público municipal de Porto Alegre. Rev Bras Ciênc Mov. 2015;23(3):5-13.

15. Nunes MDF, Freire, MDCM. Qualidade de vida de cirurgiões-dentistas que atuam em um serviço público. Rev Saúde Pública. 2006;40(6):1019-26.

16. Valle IR. Carreira do magistério: uma escolha profissional deliberada? Rev Bras Estud Pedag. 2006;87(216):178-87.

17. Hallal, PC, Carvalho YM, Tassitano RM, Tenório MCM, Warschauer M, Reis RS, et al. Avaliação quali-quantitativa do programa Academia da Cidade, Recife (PE): concepções dos professores. Rev Bras Ativ Fís Saúde. 2009;14(1):9-14.

18. Soratto J, Pires DEP, Scherer MDA, Witt RR, Ceretta LB, Farias JM. Satisfação dos profissionais da Estratégia saúde da família no Brasil: um estudo qualitativo. Texto contexto enferm. 2020;29,e20180104:1-12.

19. Rocha JFDR, Evangelista BMP, Ferreira BL, Costa FM, Carneiro JA. A satisfação profissional da equipe de enfermagem: uma revisão de literatura. EFDesportes.com, Rev Dig. 2015;19:202.

20. Tambasco LDP, Silva HSD, Pinheiro KMK, Gutierrez BAO. A satisfação no trabalho da equipe multiprofissional que atua na Atenção Primária à Saúde. Saúde Debate. 2017;41:14051.

21. Assunção AÁ, Pimenta AM. Job satisfaction of nursing staff in the public health network in a Brazilian capital city. Ciênc Saú Colet. 2020;25(1):169-80.

22. Saporetti GM, Miranda PSC, Belisário SA. The physical education professional and the promotion of health at family health support centers. Trab Educ Saúde. 2016;14(2);523-43.

23. Guarda FRB, Silva RN, Feitosa WMN, Santos Neto PM, Araújo Junior JLAC. Characterization of physical activity program teams and their work process. Rev Bras Ativ Fís Saúde. 2015;20(6):638-46.

24. Leão AL, Barbosa-Branco A, Neto EL; Ribeiro CA, Turchi, MD. Absenteísmo-doença no serviço público municipal de Goiânia. Rev Bras Epidemiol. 2015;18(1):262-77.

Received: 30/06/2020

Approved: 20/11/2020

Quote this article as:

Albuquerque AEMT, Silva BCR, Lemos EC, Moura VLG, Silva CBG, Marins AM. Job satisfaction and absenteeism of professionals in the Academia da Cidade Program in Brazil. Rev Bras Ativ Fís Saúde. 2020;25:e0164. DOI: 10.12820/rbafs.25e0164 